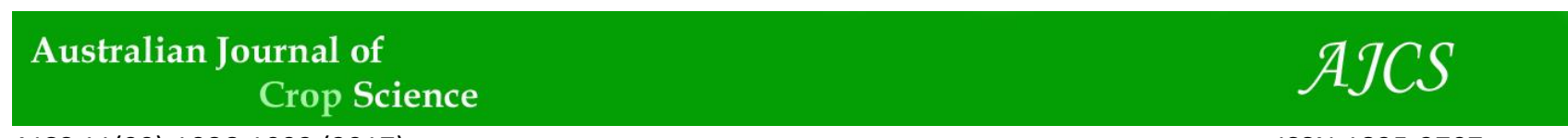

AJCS 11(09):1086-1093 (2017)

ISSN:1835-2707

doi: 10.21475/ajcs.17.11.09.pne422

\title{
Do the nutrition and physiology of eucalyptus seedlings respond to silicon ( $\mathrm{Si}$ ) supply?
}

\section{Nikolas de Souza Mateus ${ }^{1 *}$, Eric Victor de Oliveira Ferreira ${ }^{2}$, Fábio Henrique Silva Floriano de Toledo ${ }^{1}$, José Lavres ${ }^{3}$ and José Leonardo de Moraes Gonçalves ${ }^{1}$}

\author{
${ }^{1}$ University of São Paulo, São Paulo, Brazil \\ ${ }^{2}$ Federal University of São João Del Rei (UFSJ), Minas Gerais, Brazil \\ ${ }^{3}$ University of São Paulo, Center for Nuclear Energy in Agriculture, São Paulo, Brazil
}

*Corresponding author: nikolas_mateus@hotmail.com

\begin{abstract}
In Brazil, Eucalyptus plantations are found, generally in soils with naturally low chemical fertility. Silicon (Si) can improve photosynthesis, decrease plant transpiration and increase water use efficiency (WUE). This study aimed to evaluate the effect of Si supply at five rates $\left(0,0.25,0.50,0.75\right.$ and $\left.1.00 \mathrm{mmol} \mathrm{L}^{-1}\right)$ for growing Eucalyptus clone IPB8 seedlings (E. urophylla $\times$ E. grandis) in Clark's nutrient solution in a greenhouse. Plant growth, nutritional status, gas exchange, leaf water potential ( $\left.\Psi_{\mathrm{w}}\right)$, leaf area $(L A)$, inclination angle of leaves and stomatal density (SD) were measured. There was no significant response in Eucalyptus seedling growth due to $\mathrm{Si}$ application, which was related to the absence of benefits provided by $\mathrm{Si}$ in plant nutritional status and physiology. The efficiency of assimilation (EA), efficiency of translocation (ET) and efficiency of utilization (EU) did not show significant results either. The low ET indicates that $\mathrm{Si}$ was highly accumulated in the root (75.4\% in relation to total $\mathrm{Si}$ absorbed by plants), which may also have contributed to the lack of the benefits expected. Despite that, Si application promoted higher rates of photosynthesis when compared to plants with $0 \mathrm{mmol} \mathrm{Si} \mathrm{L}{ }^{-1}$, increasing the total dry matter production by up to $28 \%$ at an $\mathrm{Si}$ rate $0.50 \mathrm{mmol} \mathrm{L}^{-1}$, which also provided a trend of higher growth, EU, LA and SLA, showing it to be the best rate for this Eucalyptus species.
\end{abstract}

Keywords: beneficial element; forest nutrition; growth; nutrient solution; plant physiology.

Abbreviations: EA_efficiency of assimilation; ET_efficiency of translocation; EU_efficiency of utilization; LA_leaf area; SLA_specific leaf area; $\Psi_{\mathrm{w} \_}$leaf water potential; Si_silicon; SD_stomatal density; WUE_water use efficiency..

\section{Introduction}

Eucalyptus, the most widely planted forest species in Brazil, is susceptible to water stress which, together with an absence of fertile soil for its growth, represents the main limiting factor impairing its persistence and productivity (Gonçalves, 2010; IBÁ, 2016). Growth and wood yield responses in Eucalyptus plantations, in tropical conditions, to fertilization with $\mathrm{N}, \mathrm{P}$ and $\mathrm{K}$ nutrients are documented in the literature (Melo et al., 2016). Si is considered a beneficial element, non-essential for plants (Ma and Yamaji, 2006), being the second most abundant element in the earth's crust (Marschner, 2012). Si may increase the quality and productivity of plantations and is absorbed as silicic acid $\left(\mathrm{H}_{4} \mathrm{SiO}_{4}\right)$. Si has beneficial effects on many species of plants, especially under conditions of abiotic (salinity, metal toxicity, nutrient imbalance) and biotic stresses (lodging, drought, radiation, high temperature, freezing) (Crusciol et al., 2009). It is deposited in epidermal cell walls as amorphous silica $\left(\mathrm{SiO}_{2} \cdot \mathrm{nH}_{2} \mathrm{O}\right)$ after water evaporation (Korndörfer et al., 2004a), interfering directly in transpiration rates, as it reduces the plant's water consumption, makes more erect leaves and provides higher photosynthetic rates once leaf erectness affects light interception (Pulz et al., 2008; Marschner, 2012; Campoe et al., 2013). Since leaf angle defines the proportion of radiation that penetrates the tree canopy, the leaf architecture also affects transpiration (Whitehead and Beadle, 2004).
$\mathrm{Si}$ also reduces the incidence of fungi and bacteria, for two reasons. The first is that $\mathrm{Si}$ promotes the formation of a physical barrier deposited beneath the cuticle, hampering hyphae growth (Datnoff et al., 1997). The second reason is that soluble $\mathrm{Si}$ acts as a modulator of host resistance to pathogens, activating some defense mechanisms ( $\mathrm{Ma}$ and Yamaji, 2006). $\mathrm{SiO}_{2}$ combines with water molecules $\left(2 \mathrm{H}_{2} \mathrm{O}\right)$, forming $\mathrm{H}_{4} \mathrm{SiO}_{4}$ which can be considered as a "water deposit" (Carvalho et al., 2003), being important during periods of water stress by providing water to the plants, since water is the most limiting factor for plant growth in tropical regions (Stape et al., 2004).

Plant species differ in their ability to uptake and accumulate $\mathrm{Si}$; according to the $\mathrm{SiO}_{2}$ percentage in shoot dry matter, it is possible to classify plants as: $\mathrm{Si}$ accumulators (100 to $150 \mathrm{~g} \mathrm{SiO}_{2} \mathrm{~kg}^{-1}$ ), intermediary (10 to $50 \mathrm{~g} \mathrm{SiO}_{2} \mathrm{~kg}^{-1}$ ) and non-accumulators $\left(<5 \mathrm{~g} \mathrm{SiO}_{2} \mathrm{~kg}^{-1}\right)$ (Ma and Takahashi, 2002; Marschner, 2012). This percentage is affected by the nutritional efficiency in plants, defined as the EA, ET and EU (Clark, 1983). EA is defined as the capacity for nutrient acquisition in low availability conditions which optimizes fertilization recovery, especially in the initial stages of plant development (Barros and Novais, 1990). ET refers to the transportation of nutrients to photosynthetically active sites of the plant, being influenced by the nutritional status of root cells and the transpiration rate (Abichequer and Bohnen, 
1998). EU is the ability to use nutrients in biomass synthesis, influencing its productivity or the economy of nutrient export (Clarkson and Hanson, 1980).

In Gramineae, like rice (Zanão et al., 2010), corn (Goussain et al., 2002), Brachiaria (Sarto et al., 2016) and sugar cane (Camargo et al., 2014), the positive responses to $\mathrm{Si}$ application are well documented. In these $\mathrm{Si}$ accumulator species the element increases the photosynthetic rate and water use efficiency, and enhances the resistance of plants to plagues, diseases and water stress tolerance. Despite the literature being replete with positive plant growth responses to $\mathrm{Si}$ application (Epstein, 1999), there is a lack of information related to Si nutrition in tree species. According to Carvalho et al. (2003), even in non-accumulators, a positive response in plant growth and total dry matter production was observed in Eucalyptus with $\mathrm{Si}$ supply. However, little effort has been dedicated to analyze this element's behavior in Eucalyptus (Duarte and Coelho, 2011), indicating the need for more information to better understand Eucalyptus responses to $\mathrm{Si}$ application, during its early growth.

Considering the above, it is expected that Si supply would lead Eucalyptus seedlings to have higher yield and quality, by increasing their photosynthetic rates, water use efficiency and leaf angle, among others. Therefore, this study aimed to verify the Eucalyptus response to Si supply and its benefits on the growth, gas exchange, nutritional efficiency and organs of higher accumulation in the plant (root or leaf), as well as related factors.

\section{Results}

\section{Plant growth (height and diameter)}

From 28 days at the application rate of $0.50 \mathrm{mmol} \mathrm{Si} \mathrm{L}^{-1}$, the seedlings started to differentiate from the other treatments, both in height and diameter, keeping ahead of others until the experiment end (Figure 1a and b). In contrast, the application rates of 0.75 and $0 \mathrm{mmol} \mathrm{L}^{-1}$ showed the smallest height and diameter of plants, causing a reduction of 17 and $14 \%$, respectively.

\section{Root, shoot and total dry matter production and root/shoot ratio}

The Si application did not influence dry matter production of Eucalyptus seedlings (p > 0.05). Nevertheless, the application rate of $0.50 \mathrm{mmol} \mathrm{Si} \mathrm{L} \mathrm{L}^{-1}$ provided a trend of higher root, shoot and total dry matter production (Figure 2a, b and c) with a $28 \%$ increase in total dry matter compared to the control $\left(0 \mathrm{mmol} \mathrm{Si} \mathrm{L}{ }^{-1}\right)$. The root/shoot ratio was not affected by the $\mathrm{Si}$ application (Figure 2d), although $1 \mathrm{mmol} \mathrm{Si} \mathrm{L}^{-1}$ presented a trend of lower root/shoot ratio.

\section{Si concentration and accumulation and EA, ET and EU}

The effects of Si application rates on Eucalyptus seedlings were significant only for Si concentration in roots and leaves, according to the linear model (Figure 3a). The increase in $\mathrm{Si}$ concentration (roots and leaves) in treatments with higher $\mathrm{Si}$ rates indicates that: (i) the $\mathrm{Si}$ treatment rates were well applied and (ii) the plants were able to uptake this element by the roots and carry it to the leaves, but in a small amount, since there was large Si accumulation in roots (Figure $3 b$ ). EA did not show significant differences; however, a trend of linear growth with higher Si rates was noted (Figure 3c). A trend of positive response to $\mathrm{Si}$ application in accumulation
(Figure $3 \mathrm{~b}$ ) and EA could be verified, when compared to 0 mmol Si $\mathrm{L}^{-1}$. No significant results were found for ET ( $\mathrm{p}>$ $0.05)$, since the application rate of $0 \mathrm{mmol} \mathrm{Si} \mathrm{L}^{-1}$ had an average value higher than the others (Figure 3d). EU did not show significant values either $(\mathrm{p}>0.05)$. The lowest numerical EU value (Figure 3e) was shown at the higher rate $\left(1 \mathrm{mmol} \mathrm{Si} \mathrm{L}{ }^{-1}\right)$, which indicates the low efficiency in using this element to synthesize biomass, even with greater EA (Figure 3c) and ET (Figure 3d).

\section{Gas exchange $\left(A, C_{i} / C_{w}, g_{s}, E, W U\right)$ and $\Psi_{w}$}

The effect of $\mathrm{Si}$ application in nutrient solution on gas exchange of Eucalyptus seedlings was not significant (Figure 4). The addition of $\mathrm{Si}$ promoted higher values of photosynthesis (A) (Figure 4a) when compared to its omission. Despite that, this variable presented an average value of $13 \mu \mathrm{mol} \mathrm{m} \mathrm{s}^{-1}$ and a trend of higher photosynthetic rates at intermediary $\mathrm{Si}$ rates. The leaf internal and external $\mathrm{CO}_{2}$ concentration ratio, $C_{\mathrm{i}} / C_{\mathrm{a}}$, did not show significant regression (Figure $4 \mathrm{~b}$ ). The reduction of stomatal conductance $\left(g_{\mathrm{s}}\right)$ and transpiration $(E)$ (Figure $4 \mathrm{c}$ and d) was not significantly affected by $\mathrm{Si}$ application in the present study. The WUE (Figure 4e) was not significant either, with the higher rate $\left(1 \mathrm{mmol} \mathrm{Si} \mathrm{L}{ }^{-1}\right)$ showing a lower numerical value.

Neither did Si application change the $\Psi_{\mathrm{w}}$ of Eucalyptus seedlings in nutrient solution $(\mathrm{p}>0.05)$, either at dawn (5 $\mathrm{am})$ or at noon $(12 \mathrm{pm})$ (Figure $4 \mathrm{f})$. The highest and lowest $\Psi_{\mathrm{w}}$ values found in the coldest and hottest periods (5 am and $12 \mathrm{pm}$ ) showed average values of -0.23 and $-1.32 \mathrm{MPa}$, respectively.

\section{LA, SLA, inclination angle of leaves and SD}

Si supply did not affect $(p>0.05)$ the LA and SLA of Eucalyptus seedlings (Figure 5a and b). Despite the lack of statistical significance, it was verified that the rate of 0.5 mmol Si L ${ }^{-1}$ showed the highest mean values for both variables, while higher rates $\left(0.75\right.$ and $\left.1.00 \mathrm{mmol} \mathrm{Si} \mathrm{L}{ }^{-1}\right)$ provided lower average values. The inclination angle of leaves (Figure 5c) and SD (Figure 5d) were not affected by Si rates. It was noted that there was a small difference among $\mathrm{Si}$ rates and angle of inclination, with a mean value of $73^{\circ}$. In addition, the $0.50 \mathrm{mmol} \mathrm{Si} \mathrm{L}{ }^{-1}$ rate showed a trend of lower $\mathrm{SD}$, even when compared to the $0 \mathrm{mmol} \mathrm{Si} \mathrm{L^{-1 }}$ rate.

\section{Discussion}

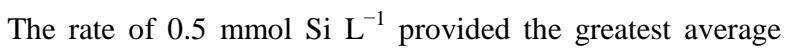
height, whereas both the absence and the highest rates of $\mathrm{Si}$ were detrimental to seedling growth in nutrient solution. Higher Si rates may precipitate the other nutrients in the solution, as observed by Bognola et al. (2011). The positive effects seen at lower rates of $\mathrm{Si}$ application might have been caused by morphological and physiological changes in the plants, providing higher photosynthetic and lower transpiration rates, as observed by Marschner (2012). Silva and Coelho (2010), who investigated the effects of lime and silicate application in a Eucalyptus clone (E. urophylla $\times E$. grandis) in a field experiment, verified that both sources promoted plant growth in terms of height and diameter at breast height.

As this study was realized in nutrient solution, the short cultivation time of treatments (60 days) could also have limited the difference in growth provided by the Si supply. 


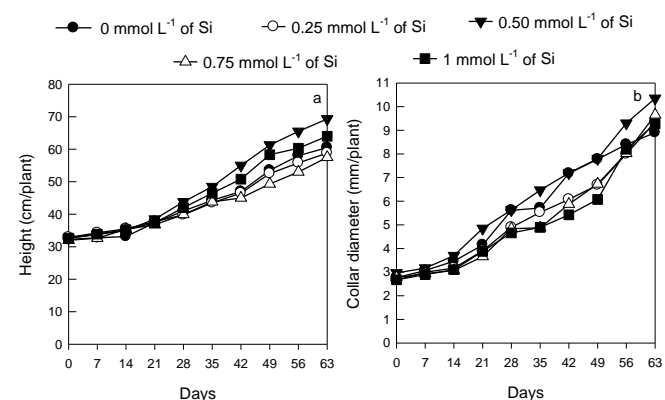

Fig 1. Weekly growth in height (a) and collar diameter (b) of Eucalyptus seedlings submitted to Si application rates in nutrient solution.
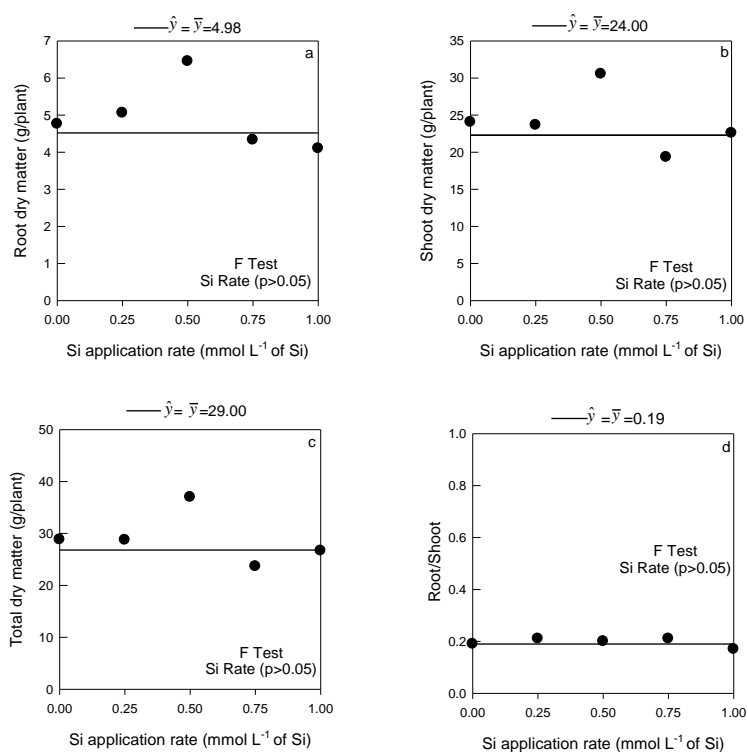

Fig 2. Root (a), shoot (b) and total dry matter production (c) and root/shoot dry matter production (d) of Eucalyptus seedlings submitted to $\mathrm{Si}$ application rates in nutrient solution.
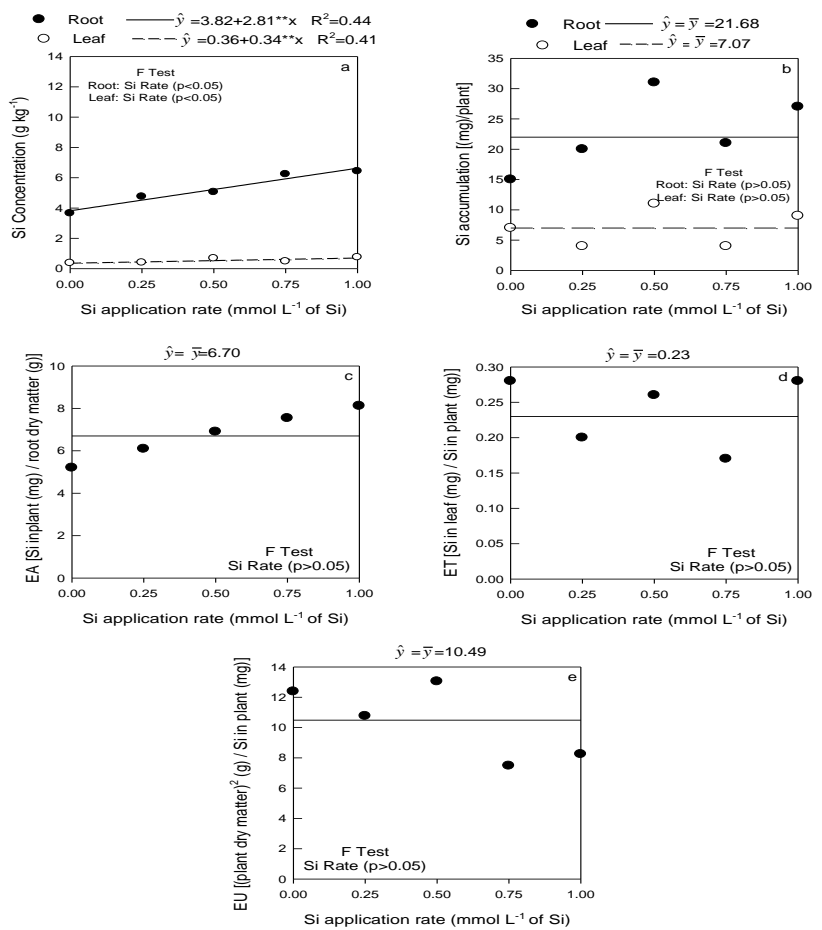

Fig 3. Si concentration (a) and accumulation (b) in roots and leaves, efficiency of Si assimilation -EA (c), of translocation - ET (d), and of utilization - EU (e) of Eucalyptus seedlings submitted to $\mathrm{Si}$ application rates in nutrient solution. ** represents significance at $1 \%$ by $\mathrm{F}$ test $(\mathrm{p}<0.05)$. 

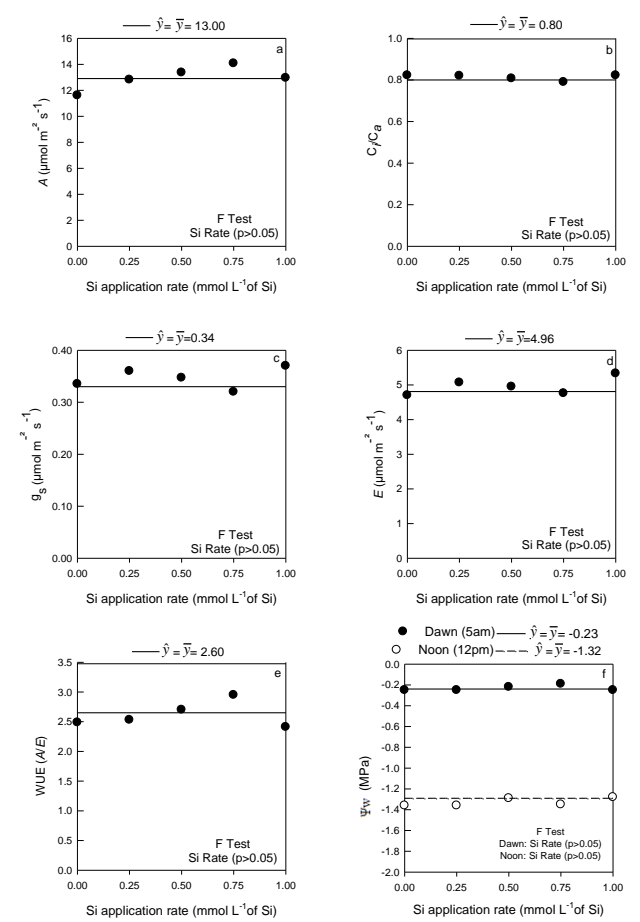

Fig 4. Gas exchange of Eucalyptus seedlings submitted to Si application rates in nutrient solution: photosynthesis - A (a), leaf internal $\left(C_{\mathrm{i}}\right)$ and external $\left(C_{\mathrm{a}}\right) \mathrm{CO}_{2}$ concentration ratio $-C_{\mathrm{i}} / C_{\mathrm{a}}(\mathrm{b})$, stomatal conductance $-g_{\mathrm{s}}(\mathrm{c})$, transpiration $-E(\mathrm{~d})$, water use efficiency - WUE (e) and leaf water potential $-\Psi_{\mathrm{w}}(\mathrm{f})$.
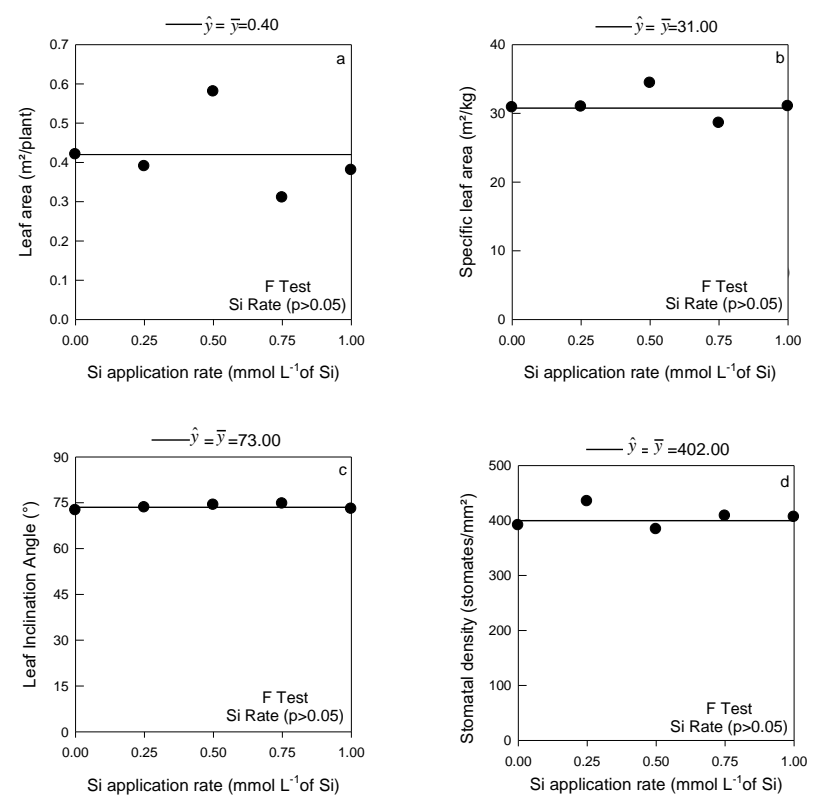

Fig 5. Leaf area - LA (a), specific leaf area - SLA (b), leaf inclination angle (c) and stomatal density - SD (stomates $\left./ \mathrm{mm}^{2}\right)(\mathrm{d})$ of Eucalyptus seedlings submitted to Si application rates in nutrient solution.

We can presume that $\mathrm{Si}$ application could even induce indirect positive responses, since this element in soil can provide effects like reducing toxic metal levels (Crusciol et al., 2009) and increasing the availability of $\mathrm{P}$ (Carvalho et al., 2000), which is not seen in nutrient solution. Higher Si rates ( 0.75 and $1.00 \mathrm{mmol} \mathrm{L}^{-1}$ ) promoted the lowest mean values for all compartments of dry matter production, as also observed for height and collar diameter (Figure 1a and b). Perhaps the greater rise in nutrient solution $\mathrm{pH}$ provided by higher Si rates could have hindered the growth of seedlings, since this species is adapted to acidic soil conditions
(Gonçalves, 2010). The same decline in growth due to $\mathrm{pH}$ increase was observed by Rocha et al. (2008) in lime application and by Bologna et al. (2011) with $\mathrm{CaSiO}_{3}$ and $\mathrm{K}_{2} \mathrm{SiO}_{3}$ application in Eucalyptus seedlings. Despite the nutrient solution $\mathrm{pH}$ having been adjusted just once after $\mathrm{Si}$ application in the treatments, the small difference in time between the $\mathrm{Si}$ application and $\mathrm{pH}$ adjustment could have occasioned nutrient precipitation, since $\mathrm{pH}$ increased concomitantly with higher rates $\left(\mathrm{pH}=9.0\right.$ in $\left.1 \mathrm{mmol} \mathrm{Si} \mathrm{L}^{-1}\right)$. A possible explanation for the root/shoot ratio results, which express the balance between the assimilatory system and its 
redistribution to other organs, is that membrane damage may have occurred in roots at high $\mathrm{pH}$, which allowed the loss of nutrients previously absorbed by the plants (Malik, 2002) as well as providing a smaller root area for nutrient absorption. A similar higher $\mathrm{Si}$ accumulation in roots was also seen by Carvalho et al. (2003) in Eucalyptus seedlings. With the present data, $7.07 \mathrm{mg} \mathrm{Si}$ per plant in leaves (Figure 3b) amounts to $15.17 \mathrm{mg} \mathrm{SiO}$ per plant. Considering shoot dry matter production (Figure $2 \mathrm{~b}$ ), the average value of leaf only dry matter was $13.08 \mathrm{~g}$ per plant; thus, plants accumulated $1.14 \mathrm{~g} \mathrm{SiO}_{2} \mathrm{~kg}^{-1}$ in shoot dry matter. Hence, according to the values obtained, this Eucalyptus clone can be classified as an Si non-accumulator, according to Marschner (2012). This reinforces the results found by Carvalho et al. (2003) who verified that $E$. grandis is not an $\mathrm{Si}$ accumulator, with $3.4 \mathrm{~g}$ $\mathrm{SiO}_{2} \mathrm{~kg}^{-1}$, and by Accioly et al. (2009), in which Eucalyptus plants had accumulated 2.2 to $3.4 \mathrm{~g} \mathrm{SiO}_{2} \mathrm{~kg}^{-1}$.

Variations in nutritional efficiency among species of Eucalyptus (Santana et al., 2002) and clones of the same species (Pinto et al., 2011) are well documented, being criteria for superior genotype selection. In this study, a possible hypothesis for the absence of a positive response in nutritional efficiency is plant age, as adult plants may be more efficient in uptake and translocation of this element (Pinto et al., 2011). Carvalho et al. (2003) observed that with advancing plant age, treatment with higher silicate rates showed greater Si translocation. The distribution of Si in the shoot is controlled by transpiration, accumulating in older tissues, because this element is not mobile within the plants (Ma and Yamaji, 2006). The responses in EU may not be due to metabolic contribution by $\mathrm{Si}$ application; this could be proved by the efficiency values obtained without Si supply, since they exceeded even the EU values observed with $\mathrm{Si}$ application, as was also observed by Carvalho et al. (2003). Another assumption is the method used to supply $\mathrm{Si}$, since foliar fertilization could possibly provide different results, since it allows assimilation by plants with low efficiency in absorbing a specific element. Greater responses to foliar $\mathrm{Si}$ application, especially in non-accumulator plants, have been verified (Marschner, 2012).

Lewis et al. (2011), studying variations among Eucalyptus species, found a similar $A$ value to this study $\left(13 \mu \mathrm{mol} \mathrm{m}{ }^{2}\right.$ $\mathrm{s}^{-1}$ ). Another benefit of $\mathrm{Si}$ application is the increase in the chlorophyll concentration of leaves (Epstein, 2001; Curvêlo et al., 2013). With this, we can presume that the $0.75 \mathrm{mmol}$ $\mathrm{Si} \mathrm{L}^{-1}$ rate provided a trend of higher photosynthetic rates, due to better leaf architecture such as higher leaf angles and chlorophyll concentration.

As expected, there was an inverse relation between $C_{\mathrm{i}} / C_{\mathrm{a}}$ (Figure 4b) and $A$ (Figure 4a) (Concenço et al., 2007). Considering a constant $C_{\mathrm{a}}$, when $A$ increases, the $C_{\mathrm{i}} / C_{\mathrm{a}}$ ratio decreases. This indicates that $C_{\mathrm{i}}$ is fixed, increasing photosynthetic rates, resulting in higher biomass. The average value of 0.8 was also seen by Mattiello et al. (2009) with different clones of Eucalyptus in nutrient solution.

According to Dayanandan et al. (1983), silica deposits in the cell walls of xylem vessels form a membrane in epidermal tissue, preventing vessel compression in water stress conditions and protecting plants against excessive loss of water by transpiration. Perhaps the low leaf $\mathrm{Si}$ accumulation may be the explanation for the absence of significant responses in $g_{\mathrm{s}}$ (Figure 4c) and $E$ (Figure 4d).

Since Si application may cause leaves to be more erect, increasing light capture and $A$, WUE can be directly affected by the supply of this element (Ma and Yamaji, 2008). However, increasing $E$ or $g_{\text {s }}$ per unit LA without increasing $A$ results in a lower WUE (Forrester et al., 2012), which can be seen at the $1 \mathrm{mmol} \mathrm{Si} \mathrm{L}^{-1}$ rate, which showed not only a trend of lower values for WUE (Figure 4e) but also for total dry matter (Figure 2c) and EU (Figure 3e). Such results indicate that less productive plants are also less efficient in their use resources (Forrester et al., 2012; Otto et al., 2014).

$\Psi_{\mathrm{w}}$ has been used to understand the leaf mechanism of dehydration avoidance; when the leaf water concentration decays, guard cells lose turgor, resulting in stomatal closure (Levitt, 1980). Facing the higher temperature at noon, which can be considered a biotic stress, it was expected that $\mathrm{Si}$ application would reduce the impact of increasing radiation (Crusciol et al., 2009), reducing transpiration rates (Pulz et al., 2008) and $\Psi_{\mathrm{w}}$ values in order to avoid leaf dehydration by excessive water loss.

Larger trees show high light use and/or light use efficiency; this combination may lead to an increase in the growth of trees (Binkley et al., 2013). Thus, we observed a strong link between the values for growth (Figure 1), total dry matter production (Figure 2c), LA and SLA (Figure 5a and b), as a consequence of greater surface area for absorbing sunlight. Pinto et al. (2009), evaluating the effect of excess zinc in the nutrient solution in Eucalyptus seedlings, observed a significantly higher $\mathrm{LA}$ with $\mathrm{Si}$ addition. SLA is an ecophysiological parameter influencing leaf physiology, photosynthesis and whole plant carbon gain, the reduction of which is an important mechanism for reducing water loss from the canopy and which may also affect carbon assimilation (Schulze et al., 2006; Nouvellon, 2010).

The leaf inclination angle is a structural property related to light distribution in the tree canopy, thus affecting plant photosynthetic rates (Leihner and Ortiz, 1978; SassenrathCole, 1995). An average value of $73^{\circ}$ was observed, similar to the range found in mature plants of $E$. maculate and $E$. globulus by Anderson (1981) and James and Bell (2000), respectively. According to these authors, Eucalyptus has a leaf angle of about $60^{\circ}$ to $80^{\circ}$, from the vertical to the horizontal, serving as an adjustment mechanism for reducing the incidence of heat under high radiation at peak times.

The SD variation related to Si rate application could be due to environmental factors, being affected by light, temperature, water status, position of a leaf on the crown and intra-leaf position. According to Pearce et al. (2006), larger stomata with lower densities could be disadvantageous in high irradiance areas, because they would tend to close slowly. We can suppose that at the $0.5 \mathrm{mmol} \mathrm{Si} \mathrm{L}^{-1}$ rate, plants had a lower mean SD, and may have had higher stomatal diameter, which was not negative, since this rate also showed the highest total dry matter production (Figure 2c) and LA (Figure 5a). Therefore, stomata were more efficient in $\mathrm{CO}_{2}$ assimilation, as a small number of stomata produced higher dry matter levels.

\section{Materials and Methods}

\section{Experimental procedure and design}

The experiment was carried out in a greenhouse at the Nuclear Energy Center in Agriculture (CENA-USP) in Piracicaba, SP, Brazil, from February to April 2015. Air temperature in the greenhouse was recorded daily and reached mean values of $31.30{ }^{\circ} \mathrm{C}$. Plants of the Eucalyptus clone IPB8 (E. urophylla $\times$ E. grandis) were cultivated for 30 days, which represented the acclimatization stage in the nutrient solution. The seedlings arrived in plastic tubes, the substrate was removed from roots by washing with tap water and then they were transplanted to a collective tray $(10 \mathrm{~L})$ with Clark's nutrient solution (1975). The nutrient solution 
was kept under permanent aeration and exchanged weekly, concomitant with a gradual increase of the original solution's concentration (25, 50, 75 and $100 \%)$. After acclimatization, homogeneous seedlings were selected, according to height and collar diameter, and transferred to individual plastic pots (3 L), where treatments were applied for 60 days.

The treatments consisted of five $\mathrm{Si}$ application rates $(0$, $0.25,0.50,0.75$ and $1.00 \mathrm{mmol} \mathrm{Si} \mathrm{L}^{-1}$ ), as potassium silicate $\left(\mathrm{K}_{2} \mathrm{SiO}_{3}\right)$, arranged in randomized blocks with four replications, making 20 experimental units with one seedling each. The nutrient solution $\mathrm{pH}$ of different treatments was adjusted to 5.5, during its exchange, by adding $\mathrm{HCl}$ or $\mathrm{NaOH}$ $\left(0.1 \mathrm{~mol} \mathrm{~L}^{-1}\right)$. In treatments with the highest $\mathrm{Si}$ application rates, the $\mathrm{pH}$ reached high values (9.0) before its correction.

\section{Measured variables}

The growth in height and collar diameter was measured weekly with a graduated ruler (in $\mathrm{cm}$ ) and a digital pachymeter (in $\mathrm{mm}$ ), respectively. Before harvesting, gas exchange was evaluated in the youngest fully expanded leaf of each seedling in the morning (7 to $11 \mathrm{am}$ ) with an infrared gas analyzer (IRGA, Li-6400xt, Licor) at environmental humidity and temperature and constant radiation $(1.000 \mu \mathrm{mol}$ $\left.\mathrm{m}^{-2} \mathrm{~s}^{-1}\right)$. Photosynthesis $(A)$, the relation between internal and external $\mathrm{CO}_{2}$ concentration $\left(C_{\mathrm{i}}\right.$ and $C_{\mathrm{a}}$, respectively), stomatal conductance $\left(g_{\mathrm{s}}\right)$, and transpiration $(E)$ were evaluated. With these data, the WUE level in the leaf was calculated by dividing values of $A$ by $E$. The leaf water potential $\left(\Psi_{\mathrm{w}}\right)$ was measured in the same type of leaves assessed for gas exchange, using a Scholander pressure chamber at dawn (5 am) and at noon (12 pm) (Turner, 1981). The inclination angle 20 leaves per plant was measured with a protractor, randomly selected from all regions and sides of the canopy (Campoe et al., 2013). Four leaves were collected in the middle region of the canopy (one on each side) per plant, for SD evaluation (stomates per $\mathrm{mm}^{2}$ ) on the abaxial leaf surface by printing on a glass slide. The sampled foliar region was pressed for $10 \mathrm{~s}$ against a drop of superglue on the glass slide. Then, using an optical microscope with $10 x$ objective magnification and a digital camera attached, three random fields of $0.116 \mathrm{~mm}^{2}$ each were photographed. Stomatal counting was done using the ImageJ program with $150 \times$ zoom, and finally the average SD was calculated (Segatto et al., 2004).

After 90 days of cultivation in the nutrient solution, the seedlings, which had their leaves sprayed with deionized water to remove dust, were harvested and their leaves, stems, branches and roots were separated. All leaves, including those previously used for SD analysis, were kept refrigerated to avoid dehydration until delivery to the laboratory for determination of LA, which was obtained with a leaf area integrator (LI-3100). Later, the leaves, stems, branches and roots were oven-dried $\left(65{ }^{\circ} \mathrm{C}\right)$ until constant weight was achieved. Afterwards, each part was weighed to obtain its dry matter. The roots and leaves were ground (Willey mill) and sent for chemical analysis at the Federal University of Uberlândia to evaluate the $\mathrm{Si}$ concentration (Korndörfer, 2004b).

With $\mathrm{Si}$ concentration values and the dry matter of each part, $\mathrm{Si}$ accumulation was calculated [accumulation = concentration $(\mathrm{g} / \mathrm{kg}) \times$ dry matter $(\mathrm{g})]$ in roots and leaves. It was also possible to calculate the nutritional efficiency of plants, through Si quantities EA, ET, and EU, suggested by Swiader et al. (1994), Li et al. (1991) and Siddiqui and Glass (1981), respectively, according to equations 1, 2 and 3. Since the $\mathrm{Si}$ concentrations were only determined in roots and leaves, to calculate the nutrient efficiency the amount of $\mathrm{Si}$ in the leaves was considered as the amount of $\mathrm{Si}$ in the shoots. The amount of Si in the plant was considered as the sum of the $\mathrm{Si}$ amount in the roots and shoots. To calculate the amount of $\mathrm{SiO}_{2}$ in the shoots, leaf $\mathrm{Si}$ accumulation and leaf dry matter production were considered, that is, shoots without stems and branches.

$$
\begin{aligned}
& \text { (1)EA: } \frac{\text { Si in plant }(\mathrm{mg})}{\text { dry matter of roots }(\mathrm{g})} \\
& \text { (2)ET: } \frac{\text { Si in shoots }(\mathrm{mg})}{\mathrm{Si} \text { in plant }(\mathrm{mg})} \\
& \text { (3)EU: } \frac{\text { (plant dry matter) }(\mathrm{g})}{\mathrm{Si} \text { in plant }(\mathrm{mg})}
\end{aligned}
$$

\section{Statistical analysis}

The data were submitted to analysis of variance ( $F$ test) to test the effects of $\mathrm{Si}$ on measured variables, and when significant $(\mathrm{p}<0.05)$ were evaluated by regression models by the SAS statistical package (SAS, 2004). Linear, quadratic and square root regression models were fitted to describe the relations between $\mathrm{Si}$ supply and response variables, and the significant model $(\mathrm{p}<0.05)$ with the highest determination coefficient $\left(\mathrm{R}^{2}\right)$ was selected. The graphics were done by SigmaPlot software.

\section{Conclusion}

Since Si accumulated mostly in the roots and had low leaf concentrations, the expected benefits in plant physiology, such as gas exchange and SD, did not occur significantly. However, the application rate of $0.50 \mathrm{mmol} \mathrm{Si} \mathrm{L}^{-1}$ provided a trend of higher growth, dry matter production, EU, LA and SLA, showing it to be the best rate for this Eucalyptus hybrid.

\section{Acknowledgements}

We are very grateful to the São Paulo Research Foundation (FAPESP) for financial support of the first author (scholarship; process number: 2014/16397-0), International Paper for offering the Eucalyptus seedlings for the experiment and to the Forestry Science and Research Institute (IPEF) for logistical support.

\section{References}

Abichequer AD, Bohnen H (1998) Eficiência de absorção, translocação e utilização de fósforo por variedades de trigo. Rev Bras Cienc Solo. 22(2):21-26.

Accioly AMA, Soares CRFS, Siqueira JO (2009) Silicato de cálcio como amenizante da toxidez de metais pesados em mudas de eucalipto. Pesqui Agropecu Bras. 44(2):180-188.

Anderson MC (1981) The geometry of leaf distribution in some south-eastern Australian forests. Agr Forest Meteorol. 25:195-205.

Barros NF, Novais RF (eds) (1990) Relação solo-eucalipto, 1 st edn. Folha de Viçosa, Viçosa. 330.

Binkley D, Campoe OC, Gspaltl M, Forrester DI (2013) Light absorption and use efficiency in forests: Why patterns differ for trees and stands. Forest Ecol Manag. 288:5-13.

Bognola IA, Clasen LA, Franciscon L, Gava JL, Dedecek RA (2011) Aplicação de silicatos de cálcio e de potássio e o crescimento de mudas de Eucalyptus grandis. Pesqui Florestal Bras. 31(66):83-92. 
Camargo MS, Korndorfer GH, Wyler P (2014) Silicate fertilization of sugarcane cultivated in tropical soils. Field Crop Res. 167:64-75.

Campoe OC, Stape JL, Nouvellon Y, Laclau JP, Bauerle WL, Binkley D, Le Maire G (2013) Stem production, light absorption and light use efficiency between dominant and non-dominant trees of Eucalyptus grandis across a productivity gradient in Brazil. Forest Ecol Manag. 288:14-20.

Carvalho R, Furtini Neto AE, Curi N, Fernandes LA, Oliveira AC, Jr (2000) Dessorção de fósforo por silício em solos cultivados com eucalipto. Rev Bras Cienc Solo. 24(1):69-74.

Carvalho R, Furtini Neto AE, Curi N, Resende AV (2003) Absorção e translocação de silício em mudas de eucalipto cultivadas em Latossolo e Cambissolo. Cienc Agrotec. 27(3):491-500.

Clark RB (1975) Characterization of phosphatase of intact maize roots. J Agr Food Chem. 23(3):458-460.

Clark RB (1983) Plant genotype differences in uptake, translocation, accumulation and use of mineral elements required for plant growth. Plant Soil. 72(2):175-196.

Clarkson DT, Hanson JB (1980) The mineral nutrition of higher plants. Ann Rev Plant Physiol. 31(1):239-298.

Concenço G, Ferreira EA, Silva AA, Ferreira FA, Viana RG, D'Antonino LI, Vargas L, Fialho CMT (2007) Water use in Italian ryegrass (Lolium multiflorum) biotypes under competition. Planta Daninha. 25(3):449-455.

Crusciol CAC, Pulz AL, Lemos LB, Soratto RP, Lima GPP (2009) Effects of silicon and drought stress on tuber yield and leaf biochemical characteristics in potato. Crop Sci. 49(3):949-954.

Curvêlo CRS, Rodrigues FA, Pereira LF, Silva LC, Damatta FM, Berger PG (2013) Trocas gasosas e estresse oxidativo em plantas de algodoeiro supridas com silício e infectadas por Ramularia aréola. Bragantia. 72(4):346-359.

Datnoff LE, Deren CW, Snyder GH (1997) Silicon fertilization for disease management of rice in Florida. Crop Prot. 16(6):525-531.

Dayanandan P, Kaufman PB, Franklin CL (1983) Detection of silica in plants. Am J Bot. 70(7):1079-1084.

Duarte IN, Coelho L (2011) Uso do silício no cultivo de mudas de eucalipto. Enciclopédia Biosfera. 7:1-10.

Epstein E (1999) Silicon. Ann Rev Plant Physio. 50:641-664.

Epstein E (2001) Silicon in plants: Facts vs concepts. In: Datnoff LE, Snyder GH, Korndörfer GH (eds) Silicon in agriculture, 1st edn. Elsevier, Amsterdam. 403.

Forrester Di, Collopy JJ, Beadle CL, Warren CR, Baker TG (2012) Effect of thinning, pruning and nitrogen fertiliser application on transpiration, photosynthesis and water-use efficiency in a young Eucalyptus nitens plantation. Forest Ecol Manag. 266:286-300.

Gonçalves JLM (2010) Eucalipto. In: Prochnow LI, Casarin V, Stipp SR (eds) Boas práticas para o uso eficiente de fertilizantes- Culturas, 3rd edn. IPNI, Piracicaba. 309-369.

Goussain MM, Moraes JC, Carvalho JG, Nogueira NL, Rossi ML (2002) Efeito da aplicação de silício em plantas de milho no desenvolvimento biológico da lagarta-do-cartucho Spodoptera frugiperda (J.E. Smith) (Lepidoptera: Noctuidae). Neotrop Entomol. 31(2): 305-310.

Indústria Brasileira de Árvores (2016) São Paulo. 96.

James SA, Bell DT (2000) Leaf orientation, light interception and stomatal conductance of Eucalyptus globulus spp. globulus leaves. Tree Physiol. 20(12):815-823.

Korndörfer GH, Pereira HS, Camargo MS (2004a) Silicatos de cálcio e magnésio na agricultura, 3rd edn. GPSi-ICIAGUFU, Uberlândia. 24.
Korndörfer GH, Pereira HS, Nolla A (2004b) Análise de silício: Solo, planta e fertilizante, 1 st edn. GPSi-ICIAGUFU, Uberlândia. 50.

Leihner DE, Ortiz G (1978) Improvement of durum wheatplant type, yield potential, and adaptation. Euphytica. 27(3):785-799.

Levitt J (1980) Responses of plants to environmental stress. Water relation, salt and other stresses, 2nd edn. Academic Press, New York. 607.

Lewis JD, Phillips NG, Logan BA, Hricko C, Tissue DT (2011) Leaf photosynthesis, respiration and stomatal conductance in six Eucalyptus species native to mesic and xeric environments growing in a common garden. Tree Physiol. 31(9):997-1006.

Li B, McKeand SE, Allen HL (1991) Genetic variation in nitrogen use efficiency of loblolly pine seedlings. Forest Sci. 37(2):613-626

Ma JF, Takahashi E (2002) Soil, fertilizer, and plant silicon research in Japan, 1st edn. Elsevier, Amsterdam. 294.

Ma JF, Yamaji N (2006) Silicon uptake and accumulation in higher plants. Trends Plant Sci. 11(8):392-397.

Ma JF, Yamaji N (2008) Functions and transport of silicon in plants. Cell Mol Life Sci. 65(19):3049-3057.

Malik KA (2002) Prospects of saline agriculture in Pakistan: Today and tomorrow. In: Ahmad R, Malik KA (eds) Prospects for saline agriculture, 1st edn. Kluwer Academic Publisher, Pakistan. 1-6.

Marschner H (2012) Mineral nutrition of higher plants, 3rd edition. Academic Press, London. 651.

Mattiello EM, Ruiz HÁ, Silva IR, Guerra PC, Andrade VM (2009) Características fisiológicas e crescimento de clones de eucalipto em resposta ao boro. Rev Arvore. 33(5):821830

Melo EASC, Gonçalves JLM, Rocha JHT, Hakamada RE, Bazani JH, Wenzel AVA, Arthur JC, Jr, Borges JS, Malheiros R, Camargo Zani de Lemos C, de Oliveira Ferreira EV, de Vicente Ferraz A (2016) Responses of clonal eucalypt plantations to $\mathrm{N}, \mathrm{P}$ and $\mathrm{K}$ fertilizer application in different edaphoclimatic conditions. Forests. $7(1): 1-15$.

Nouvellon Y, Laclau JP, Epron D, Kinana A, Mabiala A, Roupsard O, Bonnefond JM, Le Maire G, Marsden C, Bontemps JD, Saint André L (2010) Within-stand and seasonal variations of specific leaf area in a clonal Eucalyptus plantation in the Republic of Congo. Forest Ecol Manag. 259(9):1796-1807.

Otto MSG, Hubbard RM, Binkley D, Stape JL (2014) Dominant clonal Eucalyptus grandis $\mathrm{x}$ urophylla trees use water more efficiently. Forest Ecol Manag. 328:117-121.

Pearce DW, Millard S, Bray DF, Rood SB (2006) Stomatal characteristics of riparian poplar species in a semi-arid environment. Tree Physiol. 26(2):211-218.

Pinto SIC, Furtini Neto AE, Neves JCL, Faquin V, Moretti BS (2011) Eficiência nutricional de clones de eucalipto na fase de mudas cultivados em solução nutritiva. Rev Bras Cienc Solo. 35(2):523-533.

Pinto SIC, Ramos SJ, Araujo JL, Faquin V (2009) Silício como amenizador da fitotoxidez de zinco em plantas jovens de Eucalyptus urophylla cultivadas em solução nutritiva. Rev Arvore. 33(6):1005-1014.

Pulz AL, Crusciol CAC, Lemos LB, Soratto RP (2008) Influência de silicato e calcário na nutrição, produtividade e qualidade da batata sob deficiência hídrica. Rev Bras Cienc Solo. 32(4):1651-1659.

Rocha JBO, Pozza AAA, Carvalho JG, Silva CA, Curi N (2008) Efeito da calagem na nutrição mineral e no 
crescimento inicial do eucalipto a campo em latossolo húmico da Zona da Mata (MG). Sci For. 36(80):255-263.

Santana RC, Barros NF, Neves JCL (2002) Eficiência nutricional e sustentabilidade da produção em procedências de Eucalyptus grandis e Eucalyptus saligna em sítios florestais do Estado de São Paulo. Rev Arvore. 26(4):447457.

Sarto MVM, Lana MC, Rampim L, Rosset JS, Inagaki AM, Bassegio D (2016) Effects of silicon (Si) fertilization on gas exchange and production in Brachiaria. Aust J Crop Sci. 10(3):307-313.

Sassenrath-Cole GF (1995) Dependence of canopy light distribution on leaf and canopy structure for two cotton (Gossypium) species. Agr Forest Meteorol. 77(1-2):55-72.

Schulze ED, Turner NC, Nicolle D, Schumacher J (2006) Leaf and wood carbon isotope ratios, specific leaf areas and wood growth of Eucalyptus species across a rainfall gradient in Australia. Tree Physiol. 26(4):479-492.

Segatto FB, Bisognin DA, Benedetti M, Costa LCDE, Rampelotto MV, Nicoloso FT (2004) Técnica para o estudo da anatomia da epiderme foliar de batata. Cienc Rural. 34(5): 1597-1601.
Siddiqui MY, Glass ADM (1981) Utilization index: A modified approach to the estimation and comparison of nutrient utilization efficiency in plants. J Plant Nutr. 4(3):289-302.

Silva JC, Coelho L (2010) Lime and silicate applied in eucalypt: Effect on soil and plant. Biosci J. 26(6):919-924.

Stape JL, Binkley D, Ryan MG (2004) Eucalyptus production and the supply, use and efficiency of use of water, light and nitrogen across a geographic gradient in Brazil. Forest Ecol Manag. 193(1-2):17-31.

Swiader JM, Chyan Y, Freiji FG (1994) Genotypic differences in nitrate uptake and utilization efficiency in pumpkin hybrids. J Plant Nutr. 17(10):1687-1699.

Turner NC (1981) Techniques and experimental approaches for the measurement of plant water status. Plant Soil. 58(1):339-366.

Whitehead D, Beadle CL (2004) Physiological regulation of productivity and water use in Eucalyptus: A review. Forest Ecol Manag. 193(1-2):113-140.

Zanão LA, Jr, Fontes RLF, Neves JCL, Korndorfer GH, Ávila VT (2010) Rice grown in nutrient solution with doses of manganese and silicon. Rev Bras Cienc Solo. 34(5):1629-1639. 